\title{
Medisinfrie sykehusposter - et kunnskapsløst tiltak
}

\author{
Det er problematisk å gi statlig garanti for at psykotiske lidelser kan behandles uten medisiner.
}

I 2015 ble de regionale helseforetakene, etter ønske fra brukerorganisasjonene, pålagt av Helse- og omsorgsdepartementet å etablere et legemiddelfritt behandlingstilbud for pasienter innen psykisk helsevern, også dem med psykotiske lidelser (1). Oppdraget fra helseministeren gjennomgikk ikke vanlig faglig vurdering i Helsedirektoratet og er så uklart beskrevet at det har skapt forvirring i helseforetakene.

Oppdraget gjelder sykehusavdelinger der de behandler de som er for syke til å kunne ha nytte av et poliklinisk tilbud. Det er blitt oppfattet å være et tilbud til alle pasienter hvor de skal få alt de selv ønsker av behandling - unntatt behandling med antipsykotiske legemidler. Tiltaket er i ferd med å bli en parodi, da det er stor variasjon i hva folk ønsker og ingen krav til vitenskapelig begrunnelse. Hvert enkelt helseforetak oppretter nå sin versjon av et medikamentfritt tilbud.

\section{Psykose}

Psykose er en tilstand som kjennetegnes av realitetsbrist forårsaket av vrangforestillinger, hallusinasjoner og tankeforstyrrelser. Det kan være en akutt, forbigående og godartet tilstand, men er ofte langvarig og forbundet med betydelig funksjonssvikt, nedsatt livskvalitet og selvmordsfare.

Den vanligste psykoselidelsen er schizofreni. Forløpet av denne sykdommen kan være episodisk, med gjentagende tilbakefall, eller mer kontinuerlig. Schizofreni er vanligvis en stor utfordring for den som blir rammet og de pårørende (2).

\section{Antipsykotika}

Forkjemperne for egne medisinfrie sykehusposter hevder at antipsykotiske midler er farlige og ikke bør brukes. Men det finnes en mengde vitenskapelige studier som viser at antipsykotika bidrar til at de psykotiske symptomene blir mindre forstyrrende og plagsomme og noen ganger forsvinner. Medikamentene gjør ikke at lidelsen helbredes, men kan gi symptomreduksjon som muliggjør en psykososial tilnærming til pasientens problemer $(2,3)$.

Antipsykotika alene er mindre effektive enn antipsykotika kombinert med psykososiale intervensjoner. Derfor anbefaler alle oppdaterte behandlingsretningslinjer en slik kombinasjon $(4,5)$. Mange klarer seg på lave doser antipsykotika, men noen få trenger høyere doser $(5,6)$. Hvor lenge den medikamentelle behandlingen bør foregå, er fortsatt forskningsmessig uavklart (7).
Psykosebehandling ble frem til 1950årene gjennomført på asyl der pasientene var stuet sammen på store saler. Atferden var preget av bråk og uro, aggresjon, rastløshet, stereotypier, stupor og kritikkløshet. De som ikke var bråkete, men med vesentlig negative symptomer, ble neglisjert (8).

Antipsykotiske midler ble tatt i bruk i 1954. Det førte til en revolusjon i behandlingen av psykoselidelser som muliggjorde bruk av psykoterapi og miljøterapi (8). I tillegg kunne pasientene i langt større grad tilbakeføres til et vanlig liv utenfor sykehus. Studier

\section{«Antipsykotiske midler ble tatt i bruk i 1954. Det førte til en revolu- sjon i behandlingen av psykoselidelser»}

viste at de som startet behandling etter 1954 og dermed fikk antipsykotika tidlig i sykdomsforløpet, hadde et mer gunstig langtidsforløp enn de som fikk antipsykotika senere i forløpet $(9,10)$. Det er også vist at umedisinerte pasienter har et langt dårligere langtidsforløp enn medisinerte (11).

Antipsykotika har bivirkninger. Førstegenerasjonsmedikamentene som kom i 1954 ga ofte motoriske forstyrrelser. Vektøkning og ugunstig lipidprofil som hyppigere bivirkninger hos noen av neste generasjon antipsykotika gir økt risiko for hjerte- og karsykdommer (2). Det er imidlertid funnet lavere dødelighet hos dem som får antipsykotika i moderate eller høyere doser enn hos dem som ikke får medisiner, og dødeligheten er lavere hos dem som bruker antipsykotika enn hos dem som ikke gjør det (12-15). I dagens retningslinjer for behandling av psykose vektlegges bivirkninger som grunnlag for valg av type antipsykotika, da effekten av de forskjellige medikamentene er ganske lik.

Hos $20 \%$ av dem som har schizofreni har antipsykotika liten effekt. Problemet er at vi i dag ikke har noen markører som kan fortelle oss hvem disse er før medikamenter er prøvd. Derfor anbefales det at alle får tilbud om antipsykotika. Hos det store flertallet bidrar medisiner til symptomlette, funksjonsbedring og høyere selvrapportert livskvalitet.

\section{Tidlig intervensjon}

Flere av dem som blir diagnostisert med en psykoselidelse, har hatt psykotiske symptomer i lang tid før de blir henvist til behandling. I en norsk studie så man nærmere på om tidlig oppdagelse og behandling av psykoser bidrar til å redusere varigheten av tilstanden (16). I denne studien tok $80 \%$ av pasientene antipsykotiske midler frivillig i løpet av første behandlingsuke. $\mathrm{Ni}$ av 301 (3\%) fikk behandling uten antipsykotika.

De som var tvangsinnlagt (58,1\%), var dårligere ved innleggelsen, men tok medisiner frivillig like hyppig som de frivillig innlagte og var ikke dårligere to år senere. Pasientene oppga at de hadde brukt antipsykotika i $65,7 \%$ av oppfølgingstiden på ti år $(6,16,17)$. Det er altså ikke slik at en person med en psykoselidelse trenger medikamenter for alltid, og det er mulig å få behandling uten antipsykotika.

\section{Behandling uten medisiner}

Ikke alle responderer på medisiner, og det er en del som ikke vil bruke det, ofte på grunn av bivirkninger. Men siden det finnes en veldokumentert effekt av medikamenter, er det utført få vitenskapelige studier av behandling uten antipsykotika. Så langt vi kjenner til, er det foreløpig bare gjort én slik studie (18).

74 personer med schizofreni som ikke ønsket medisiner, ble randomisert til «vanlig behandling» med eller uten kognitiv terapi. De ble fulgt opp i 18 måneder. Kognitiv terapi ga en moderat tilleggseffekt på symptomnivå.

Det er vanskelig å trekke konklusjoner fra studien på grunn av metodologiske problemer. I alt $27 \%$ av pasientene fikk antipsykotika likevel, akutt syke ble ikke inkludert, blindingen var ikke optimal, forskerne hadde stor tiltro til kognitiv terapi og det var stort frafall. Dessuten var det en tendens til at gruppen som fikk kognitiv terapi besto av pasienter med bedre prognose. Forfatterne tar da også forbehold og anbefaler en større undersøkelse før det trekkes sikrere konklusjoner.

I denne studien ble polikliniske pasienter inkludert, ikke personer med psykoselidelse som trengte sykehusinnleggelse - nettopp den gruppen som skal få medikamentfri behandling med det nye behandlingstilbudet. 


\section{Diskusjon og konklusjon}

Medikamentell behandling av psykoselidelser har god dokumentert effekt, men er utfordrende i praksis. Den krever spesialkunnskaper og de rette holdninger hos helsepersonellet og skal alltid være en integrert del av den totale behandlingen, som inkluderer psykologiske og miljømessige tiltak.

Bivirkninger er ikke til å unngå. Oftest er de ufarlige og lite plagsomme, men er av og til alvorlige. For klinikeren gjelder det å balansere de forskjellige hensyn hos den

\section{«Vi kan vanskelig tenke} oss at myndighetene vil påby helseforetakene å etablere et cellegiftfritt tilbud for kreftpasienter eller en medikamentfri hjertebehandling uten at det foreligger faglig dokumentasjon»

enkelte pasient - nytten av medikamentene må veies opp mot bivirkningene og de alternative behandlingsmulighetene. Oftest er det mulig å få dette til på en god måte dersom det prioriteres og man setter av nok tid.

Både pasienter og behandlere skulle ønske at det var unødvendig med medisiner, men det er ønsketenkning. Det store flertallet av pasientene har nytte av antipsykotika fordi det bidrar til å gi symptomlette og bedre funksjonsevne. Et medikamentfritt tilbud for behandling av psykotiske tilstander savner foreløpig dokumentasjon om tilfredsstillende effekt og er ikke anbefalt i noen faglige retningslinjer - heller ikke de norske (5).

Ved å påby et medikamentfritt tilbud til denne gruppen pasienter sender våre myndigheter et sterkt signal. Mange vil da anta at det foreligger solid dokumentasjon bak påbudet, noe som ikke er tilfellet. Påbudet kan være et velmenende tiltak fra myndighetenes side, og det støttes av flere brukerorganisasjoner. Forkjemperne for det nye tilbudet er synlige i sosiale medier og aktive i den offentlige debatten. De dårligste pasientene har imidlertid vansker med å fremme sitt syn, og vi mener det nye tiltaket kan forverre prognosen for dem.

Helsevesenet skal på tvers av fagfelt tilby kunnskapsbasert utredning og behandling. Vi kan vanskelig tenke oss at myndighetene vil påby helseforetakene å etablere et cellegiftfritt tilbud for kreftpasienter eller en medikamentfri hjertebehandling uten at det foreligger faglig dokumentasjon. At dette nå skjer innen psykiatrifeltet, kan tyde på en devaluering av psykiatrien som fagområde.

\section{Jan Ivar Røssberg \\ j.i.rossberg@medisin.uio.no \\ Ole A. Andreassen \\ Stein Opjordsmoen IIner}

Jan Ivar Røssberg (f. 1966) er professor i psykiatri ved Institutt for klinisk medisin, Universitetet i Oslo, og overlege ved Seksjon for behandlingsforskning, Oslo universitetssykehus.

Forfatter har fylt ut ICMJE-skjemaet og oppgir ingen interessekonflikter.

Ole A. Andreassen (f. 1966) er professor i psykiatri ved Norment: Norsk senter for forskning på mentale lidelser, Universitetet i Oslo, og overlege ved Oslo universitetssykehus.

Forfatter har fylt ut ICMJE-skjemaet og oppgir følgende interessekonflikter: Han har mottatt forelesningshonorar fra Lundbeck, men ikke knyttet til dette arbeidet.

Stein Opjordsmoen Ilner (f. 1942) er spesialist i nevrologi og psykiatri og professor emeritus i psykiatri.

Forfatter har fylt ut ICMJE-skjemaet og oppgir følgende interessekonflikter: Han har mottatt honorar fra Lundbeck, Otsuka og Sunovion, men ikke knyttet til dette arbeidet.

\section{Litteratur}

1. Medikamentfri behandling for psykisk syke i alle helseregioner. https://www.regjeringen.no/no/ aktuelt/medikamentfri-behandling-for-psykisksyke-i-alle-helseregioner/id2464240/ (16.1.2017).

2. Malt UF, Andreassen OA, Melle I. Lærebok i psykiatri. 3. utg. Oslo: Gyldendal Akademisk, 2012.
3. Kapur S. Psychosis as a state of aberrant salience: a framework linking biology, phenomenology, and pharmacology in schizophrenia. Am J Psychiatry 2003; 160: 13-23.

4. National Institute for Health and Care Excellence (NICE). Psychosis and schizophrenia in adults: treatment and management, 2014.

https://www.nice.org.uk/guidance/cg178 (16.2.2017).

5. Helsedirektoratet. Utredning, behandling og oppfølging av personer med psykoselidelser. Nasjonale faglig retningslinjer. IS-1957. Oslo: Helsedirektoratet, Avdeling Psykisk helsevern og rus, 2013.

6. Opjordsmoen S, Melle I, Friis S et al. Stability of medication in early psychosis: a comparison between second-generation and low-dose firstgeneration antipsychotics. Early Interv Psychiatry 2009; 3: 58-65.

7. Wunderink L, Nieboer RM, Wiersma D et al. Recovery in remitted first-episode psychosis at 7 years of follow-up of an early dose reduction/ discontinuation or maintenance treatment strategy: long-term follow-up of a 2-year randomized clinical trial. JAMA Psychiatry 2013; 70: 913-20.

8. Jørgensen J-K, Retterstøl N. I grenseland. Fra en psykiaters liv. Oslo: Cappelen Damm, 2003.

9. Opjordsmoen S. Long-term clinical outcome of schizophrenia with special reference to gender differences. Acta Psychiatr Scand 1991; 83: 307-13.

10. Wyatt RJ. Neuroleptics and the natural course of schizophrenia. Schizophr Bull 1991; 17: 325-51.

11. Ran MS, Weng X, Chan CL et al. Different outcomes of never-treated and treated patients with schizophrenia: 14-year follow-up study in rural China. Br J Psychiatry 2015; 207: 495-500.

12. Baandrup L, Gasse C, Jensen VD et al. Antipsychotic polypharmacy and risk of death from natural causes in patients with schizophrenia: a population-based nested case-control study. J Clin Psychiatry 2010; 71: 103-8.

13. Crump C, Winkleby MA, Sundquist $K$ et al. Comorbidities and mortality in persons with schizophrenia: a Swedish national cohort study. Am J Psychiatry 2013; 170: 324-33.

14. Tiihonen J, Haukka J, Taylor M et al. A nationwide cohort study of oral and depot antipsychotics after first hospitalization for schizophrenia. Am J Psychiatry 2011; 168: 603-9.

15. Tiihonen J, Mittendorfer-Rutz E, Torniainen M et al. Mortality and cumulative exposure to antipsychotics, antidepressants, and benzodiazepines in patients with schizophrenia: an observational follow-up study. Am J Psychiatry 2016; 173: 600-6.

16. Friis S, Melle I, Johannessen JO et al. Early predictors of ten-year course in first-episode psychosis. Psychiatr Serv 2016; 67: 438-43

17. Opjordsmoen S, Friis S, Melle I et al. A 2-year follow-up of involuntary admission's influence upon adherence and outcome in first-episode psychosis. Acta Psychiatr Scand 2010; 121: 371-6.

18. Morrison AP, Turkington D, Pyle M et al. Cognitive therapy for people with schizophrenia spectrum disorders not taking antipsychotic drugs: a singleblind randomised controlled trial. Lancet 2014: 383: 1395-403.

Mottatt 25.1. 2017, første revisjon innsendt 1.2. 2017, godkjent 16.2. 2017. Redaktør: Kaveh Rashidi.

Publisert først på nett. 